Dapat diakses pada: http://jkb.ub.ac.id/index.php/jkb/article/view/2578

Jurnal Kedokteran Brawijaya Vol. 30, No. 4, Agustus 2019, pp. 259-266

Article History: Received 18 Februari 2019, Accepted 26 Mei 2019

Artikel Penelitian

\title{
Effect of Chitosan on Histology of Reproductive Organs of Female Wistar Rats (Rattus norvegicus) Exposed to Acetate Lead
}

\section{Pengaruh Kitosan terhadap Histologi Organ Reproduksi Tikus Galur Wistar (Rattus norvegicus) Betina yang Dipapar Timbal Asetat}

\author{
Alief Ayu P $P^{1}$, Annisa' Wigati ${ }^{1}$, Dwi Dianita I' ${ }^{1}$ Umi Kalsum² ${ }^{2}$, Retty Ratnawati ${ }^{3}$, Nurdiana ${ }^{2}$, Kenty Wantri $A^{4}$ \\ ${ }^{1}$ Program Studi Magister Kebidanan Fakultas Kedokteran Universitas Brawijaya Malang \\ ${ }^{2}$ Departemen Farmakologi Fakultas Kedokteran Universitas Brawijaya Malang \\ ${ }^{3}$ Departemen Faal Fakultas Kedokteran Universitas Brawijaya Malang \\ ${ }^{4}$ Departemen Patologi Anatomik Fakultas Kedokteran Universitas Brawijaya Malang
}

\begin{abstract}
Lead is one of the pollutants widely spread in the environment because it is not easily decomposed. Lead can affect system functions such as the ovary and endometrium. Lead can trigger oxidative stress by reducing antioxidant enzymes and increasing Reactive Oxygen Species (ROS). Lead can also reduce Follicle Stimulating Hormone (FSH) and Luteinizing Hormone (LH) levels by disturbing the hypothalamus. Chitosan is an antioxidant compound that can reduce the toxic effects of lead. The purpose of this study was to study the effects of chitosan administration on the diameter of antral follicles, the number of endometrial arterioles, and the thickness of endometrial rats after lead acetate exposure. This study was an experimental laboratory using a posttest-only control group design approach applied on 25 female rats aged 8 weeks old, body weight 125-175 grams. Lead and chitosan were given orally with a sonde. There were 5 groups, namely, negative control group (without any treatment), positive control group (lead $175 \mathrm{mg} / \mathrm{kg} / \mathrm{BW}$ ), treatment group 1 (lead $175 \mathrm{mg} / \mathrm{kg} / \mathrm{BW}+$ chitosan $16 \mathrm{mg} / \mathrm{kg} / \mathrm{BW}$, treatment group 2 (lead $175 \mathrm{mg} / \mathrm{kg} / \mathrm{BW}+$ chitosan $32 \mathrm{mg} / \mathrm{kg} / \mathrm{BW}$ ), and treatment group 3 (lead $175 \mathrm{mg} / \mathrm{kg} / \mathrm{BW}+$ chitosan $64 \mathrm{mg} / \mathrm{kg} / \mathrm{BW}$ ) for 30 days. The rats were sacrificed at proestrus phase, which was proven from vaginal swab. Observations were carried out using the Hematoxylin Eosin (HE) staining method. The observations were analyzed using One Way ANOVA and followed by Least Significant Differences (LSD) test. The results showed significant results ( $p$-value $<0.05)$. Chitosan can increase the diameter of the antral follicle, increase the number of endometrial arterioles, and increase the thickness of endometrial rats exposed by lead acetate.
\end{abstract}

Keywords: Antral follicles, endometrial arterioles, chitosan, lead, thickness of endometrium

\section{ABSTRAK}

Timbal merupakan salah satu polutan beracun yang banyak tersebar di lingkungan karna sifatnya yang tidak mudah terurai. Timbal dapat mempengaruhi fungsi sistem reproduksi seperti ovarium dan endometrium. Timbal dapat memicu terjadinya stres oksidatif dengan cara menurunkan enzim antioksidan dan meningkatkan Reactive Oxygen Species (ROS). Timbal juga dapat menurunkan kadar Follicle Stimulating Hormone (FSH) dan Luteinizing Hormone (LH) dengan cara menganggu hipotalamus. Kitosan merupakan salah satu senyawa antioksidan yang dapat mengurangi efek toksik dari timbal. Tujuan penelitian ini yaitu untuk mengetahui efek pemberian kitosan terhadap diamater folikel antral, jumlah arteriol endometrium, dan ketebalan endometrium tikus setelah dipapar timbal asetat. Penelitian ini merupakan experimental laboratory dengan pendekatan post test only control group design menggunakan tikus wistar betina sebanyak 25 ekor berusia 8 minggu dengan berat badan 125-175 gram. Timbal dan kitosan diberikan per oral dengan sonde. Terdapat 5 kelompok, kontrol negatif (tidak diberi perlakuan), kontrol positif (diberi timbal 175mg/Kg/BB), perlakuan 1 (timbal 175mg/Kg/BB + kitosan 16mg/Kg/BB), perlakuan 2 (timbal $175 \mathrm{mg} / \mathrm{Kg} / \mathrm{BB}+\mathrm{kitosan} 32 \mathrm{mg} / \mathrm{Kg} / \mathrm{BB}$ ), perlakuan 3 (timbal $175 \mathrm{mg} / \mathrm{Kg} / \mathrm{BB}+$ kitosan $64 \mathrm{mg} / \mathrm{Kg} / \mathrm{BB}$ ) selama 30 hari. Tikus dikorbankan pada fase proestrus yang terbukti dari swab vagina. Pengamatan dilakukan dengan metode pewarnaan HE (Haemotoksilin Eosin). Hasil pengamatan dianalisis dengan One Way ANOVA dan diikuti tes Least Significant Differences (LSD). Hasil penelitian menunjukkan hasil yang signifikan ( $p$-value $<0,05)$. Pemberian kitosan dapat meningkatkan diameter folikel antral, meningkatkan jumlah arteriol endometrium, dan menambah ketebalan endometrium tikus yang dipapar timbal asetat.

Kata Kunci: Arteriole endometrium, diameter folikel antral, ketebalan endometrium, kitosan, timbal asetat

Korespondensi: Alief Ayu P. Program Studi Magister Kebidanan Fakultas Kedokteran Universitas Brawijaya Malang, JI. Veteran 65145, Malang Tel.081230427500 Email:aliefayu23@gmail.com

DOI: http://dx.doi.org/10.21776/ub.jkb.2019.030.04.5 


\section{INTRODUCTION}

Lead is one of the toxic pollutants that is widely spread in the environment because of its non-biodegradable nature (1). One of the main sources of lead exposure is through the digestive system that comes from lead-contaminated food and beverages. The US Centers for Disease Control and Prevention regulated that the limit of lead levels in the blood for adults is $10 \mu \mathrm{g} / \mathrm{dL}$ (2). Symptoms of lead toxicity occur in continuous exposure in small amounts, so the effects of chronic lead toxicity are more common (1). Lead toxicity can affect the kidney function, the hematopoietic system, the central nervous system, and the reproductive system(3). Lead can induce oxidative stress(4).

Oxidative stress is an imbalance between antioxidants and oxidants, which are more dominant (5). Lead binds to the sulfhydryl group and causes the decrease in the levels of superoxide dismutase (SOD), catalase (CAT), and glutathione (GSH) antioxidants $(6,7)$. In addition, the sulfhydryl group binding can deactivate several enzymes in heme biosynthesis, such as ALAD (Amino Laevulinic Acid Dehydratase) (8). Decreased ALAD results in an increase in Laevulinic Amino Acid (ALA) which can stimulate the production of ROS (9). Lead is able to pass through the Blood Brain Barrier (BBB) and affect to $\mathrm{Ca}^{2+}$ as a Second Messanger by binding to $\mathrm{CaM}$, thus causing changes in cell function (10). This can affect the biosynthesis of sex hormones in the hypothalamus, the stimulus to $\mathrm{GnRH}$ is impaired so that the production of FSH and $\mathrm{LH}$ decreases (11). All of these mechanisms cause oxidative stress and a decrease in $\mathrm{FSH}$ and $\mathrm{LH}$, which will damage reproductive organs such as the ovary and endometrium(7).

In the ovary, there are follicular developments on various stages, one of which is the antral follicle phase. Antral follicles are follicles that grow due to stimulation from FSH and $\mathrm{LH}(12)$. If the process of follicular growth is disrupted, it will affect hormone production, for example, the hormone estrogen produced by the antral follicle during the process of folliculogenesis (13). In the endometrium, a decrease in the hormone estrogen can result in the regulation of Vascular Endothelial Growth Factor (VEGF), which are the key compounds of angiogenesis '(14). VEGF expression will increase during the proliferation phase, and the peak will occur in the middle phase of secretion in menstrual cycle, which is responsible for ripening the spiral arteries during the implantation window. The spiral artery is a blood vessel branching from the arcuate artery which will form arterioles which supply $9 \mathrm{~mm}^{2}$ from the endometrial layer in human (15); so, if the regulation of VEGF is impaired, it can inhibit the formation of new blood vessels through angiogenesis (16). Angiogenesis is important for endometrial growth in receiving implantation on pregnancy (17). In addition, the endometrium, whichis physiologically thickened is also important in the success of implantation and pregnancy (18). Some studies suggest that endometrial thickness is a contributing factor for fertility (19).

Several studies have shown that antioxidant administration can prevent or overcome the toxic effects of lead (20). One of the antioxidants that can be utilized is chitosan. Chitosan is a powder derived from modification of chitin compound that is widely found in the outer shells of Crustacean species such as shrimps and crabs (21). The Food and Drug Administration (FDA) has admitted that chitosan is safe for consumption (22). Chitosan can be applied as an antioxidant, antiinflammatory, antiallergic, anticoagulant, antitumor, anticancer, antibacterial, and immunostimultan (23). Chitosan has an antioxidant mechanism through its ability to stabilize free radicals (Scavenging) and is able to bind metal ions (Chelating) (20). The hydroxyl $(\mathrm{OH})$ and amino groups ( $\mathrm{NH} 2$ ) are key chitosan groups as antioxidant agents that will prevent free radicals due to lipid oxidation processes. In addition to functioning as an antioxidant, chitosan can also be an absorbent to heavy metal(21).

This study was conducted to proved the effect of oral chitosan administration on ovarian reproductive organ damage (antral follicle diameter) and endometrium (arteriole number and endometrial thickness) in Wistar rats (Rattus norvegicus) exposed to lead acetate.

\section{METHOD}

\section{Research design}

Thisin vivo study was an experimental laboratory with posttest only control group design approach. The study used female rats (Rattus norvegicus) Wistar strain exposed to lead and given antioxidants in the form of chitosan.

\section{Lead and Chitosan Solution Preparation}

The study used lead (II) acetate trihydrate with catalog number 107375 . The lead solution was made by dissolving lead acetate with distilled water according to the dosage set (24). Chitosan solution was made by dissolving chitosan and $2 \%$ acetic acid according to the dosage set.

\section{Animal Treatments}

The number of samples used in this study was 25 white female Wistar strain rats (Rattus norvegicus). The inclusion criteria in this study were Wistar strain rats (Rattus norvegicus), 8 weeks old, body weight 125-175 grams, female, healthy (clean white fur, active), not pregnant, and never been used in previous studies. The exclusion criteria in this study were rats that appeared sick before being treated. This research have approval from Ethics Commission of Faculty of Medicine, Brawijaya University No. 99/EC/KEPK-S2/03/2019.

The rats were divided into 5 groups, 2 control groups (negative and positive controls) and 3 treatment groups (given chitosan doses of $16 \mathrm{mg} / \mathrm{kg} / \mathrm{BW}, 32 \mathrm{mg} / \mathrm{kg} / \mathrm{BW}$, $64 \mathrm{mg} / \mathrm{kg} / \mathrm{BW})$. All groups were givenlead at a dose of $175 \mathrm{mg} / \mathrm{kg} / \mathrm{BW} /$ day, except for the negative control group. Provision of lead acetate and chitosan solution was carried out orally with a sonde for 30 days.

After 30-days treatment, the rat we sacridficed at the proestrus phase through vaginal smear. Before surgery, the rat was anesthetized by ketamine injection dose $0,2 \mathrm{ml}$. The parts taken were the right ovary and uterus, and soaked in Buffer Neutral Formalin (BNF) solution and the histological preparations and HE staining were conducted on Anatomy Pathology Laboratory. The rest of the carcasses were buried together with a depth of 0.5 meters under the ground without being wrapped so as not to cause environmental pollution.

\section{The procedure of Histopathological Preparations}

The histopathological preparations consist of several processes, namely: tissue cutting, tissue blocking and cutting, deparaffinization, staining process (HE), immersion in multilevel alcohol, clearing, mounting, and closing with glass cover. Before reading the histological and endometrial histological slides, histological preparations were consulted to the Anatomical Pathologist. Histological 
slide readings was using an Olympus microscope in 400 times magnification for parameters of antral follicle diameter and endometrial thickness, while 200 times magnification for the parameter of the number of endometrial arterioles.

\section{Measurement of Antral Follicle Diameter}

The first step in observing was to identify the type of follicle. Determination of antral follicles was based on the presence of antrum, an increase in the number of granulosa cells, the presence of Cumulus Oocyte Complex (COC), and theca cells surrounding the follicles. The antral follicle diameter was measured using Dot slide software with 2 intersecting lines drawn from the farthest distance of the follicle and the shortest distance of the follicles, which were then calculated and averaged.

\section{Calculation of the Number of Endometrial Arterioles}

Calculation of the number endometrial arterioles based on 10 visual fields using Olyvia software and cell counting. Determination of the number of endometrial arterioles was based on the characteristics of a thick round tissue that has intima, media, and adventitia, which are then calculated and averaged.

\section{Measurement of Endometrial Thickness}

The limit of measurement of endometrial thickness was from the epithelial lumen to the endometrial basal layer. Measurement of endometrial thickness was carried out at 12 points (which were described as the position of numbers on analog clocks) which reached 4 quadrants in the endometrium using Dot slide software, which was then calculated and averaged.

\section{Statistical Analysis}

The measurement results of antral follicle diameter, number of arterioles, and endometrial thickness of control and treatment rats were analyzed statistically using the One Way ANOVA test with a significance level of $0.05(p=0.05)$ and a confidence level of $95 \%(\alpha=0.05)$, and followed by Least Significant Differences (LSD) test.

\section{RESULTS}

Effect of Chitosan Administration on Diameter of the Antral Follicle induced by Lead

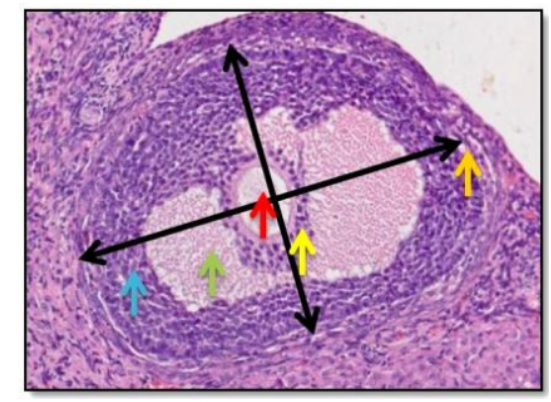

Figure 1. Microscopic antral follicle measurement at 400 times magnification

Note: Identification of antral follicles, consisting of multiplying granulosa cells (blue arrow), presence of antrum cavities (green arrow), oocytes (red arrow), expansion of cumulus cells surrounding the oocytes (yellow arrow), and theca cells (orange arrow). Measuring the diameter using 2 auxiliary lines (black arrows) on all follicles.
There are various types of follicles in the ovary, such as primordial follicle, primary follicle, secondary follicle, tertiary follicle, de Graaf follicle, and atresia follicle. The follicles are divided into 2, pre-antral follicles and antral follicles.

The One Way ANOVA test was used to compare the mean diameter of the antral follicles in the five sample groups. The Table 1 present One Way ANOVA test results on the antral follicle diameter.

One Way ANOVA test on antral follicle diameter obtained p-value $0.005(<0.05)$ which showed significant differences in the diameter of the antral follicles in each group. Next, the Least Significant Differences (LSD) test was carried out. In the LSD test, the negative control group $\left(370.34 \pm 86.25^{\circ}\right)$ compared to the positive control group $\left(173.756 \pm 37.48^{\mathrm{a}}\right)$ showed a significant difference in the diameter of the antral follicle. It showed that exposure of lead acetate in the female rat in a dose of $175 \mathrm{mg} / \mathrm{kg} / \mathrm{BW}$ could reduce the diameter of the antral follicle.

Table 1 also illustrated the comparison results of the negative control group $\left(370.34 \pm 86.25^{c}\right)$ to group P1 $\left(235.468 \pm 57.08^{\mathrm{ab}}\right)$, there was a significant difference in the mean diameter of the antral follicle. In other words, group $\mathrm{P} 1$, chitosan $16 \mathrm{mg} / \mathrm{kg} / \mathrm{BW}$ has not been able to increase the diameter of antral follicles in rats exposed to lead significantly. In addition, there were significant differences in the positive control group $\left(173.756 \pm 37.48^{\mathrm{a}}\right)$ and the P3 group $\left(340.566 \pm 112.11^{\text {bc }}\right)$. Lead + chitosan $64 \mathrm{mg} / \mathrm{kg} / \mathrm{BW}$ exposure in rats can significantly increase the diameter of the antral follicle.

Table. 1 One Way ANOVA results of antral follicle diameter between research groups

\begin{tabular}{|c|c|c|c|}
\hline Research Groups & $\mathbf{N}$ & $\begin{array}{l}\text { Mean } \pm \text { SD Antral } \\
\text { Follicle Diameter }\end{array}$ & p-value \\
\hline Negative Control (without treatment) & 5 & $370.343 \pm 86.25^{c}$ & \\
\hline Positive Control (lead acetate & 5 & $173.758 \pm 37.48^{\mathrm{a}}$ & \\
\hline $175 \mathrm{mg} / \mathrm{kg} / \mathrm{BW})$ & & & 0.005 \\
\hline $\begin{array}{l}\text { Treatment } 1 \text { (lead acetate } \\
175 \mathrm{mg} / \mathrm{kg} / \mathrm{BW}+\text { chitosan } 16 \mathrm{mg} / \mathrm{kg} / \mathrm{BW} \text { ) }\end{array}$ & 5 & $235.468 \pm 57.08^{\mathrm{ab}}$ & \\
\hline $\begin{array}{l}\text { Treatment } 2 \text { (lead acetate } \\
175 \mathrm{mg} / \mathrm{kg} / \mathrm{BW}+\text { chitosan } 32 \mathrm{mg} / \mathrm{kg} / \mathrm{BW} \text { ) }\end{array}$ & 5 & $269.357 \pm 78.29^{a b c}$ & \\
\hline $\begin{array}{l}\text { Treatment } 3 \text { (lead acetate } \\
175 \mathrm{mg} / \mathrm{kg} / \mathrm{BW}+\text { chitosan } 64 \mathrm{mg} / \mathrm{kg} / \mathrm{BW} \text { ) }\end{array}$ & 5 & $340.566 \pm 112.11^{\text {bc }}$ & \\
\hline
\end{tabular}

Note: * One Way ANOVA \& Least Significant Differences (LSD). The difference in notation indicates a significant difference ( $p$-value $<0.05$ ). However, if the notation same it means there is no significant difference ( $p$-value $>0.05$ ).

Therefore, it can be concluded that lead exposure can reduce the diameter of the antral follicles and chitosan can increase the diameter of the antral follicle. However, chitosan $16 \mathrm{mg} / \mathrm{kg} / \mathrm{BW}$ has not been able to increase the diameter of the antral follicle significantly. At a dose of $32 \mathrm{mg} / \mathrm{kg} / \mathrm{BW}$, although there was an increase in the mean diameter of the antral follicle compared to lead-exposed rat, it was not sufficient to significantly increase the diameter of the antral follicle exposed to lead. The dose of chitosan $64 \mathrm{mg} / \mathrm{kg} / \mathrm{BW}$ was able to increase the diameter of the antral follicles in rats exposed to lead significantly.

Effect of Chitosan Administration on the Number of Endometrial Arterioles Induced by Lead 


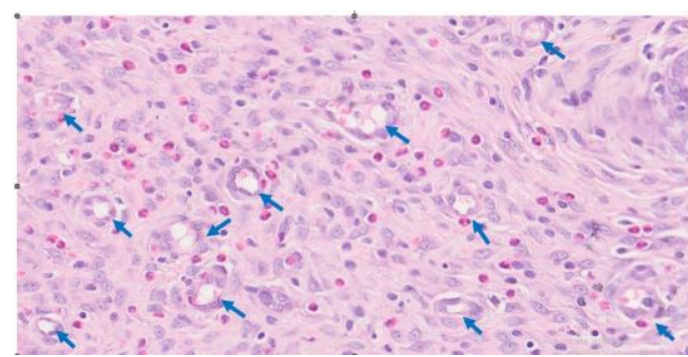

Figure 2. Microscopic calculation of the number of endometrial arterioles with 200 times magnification

Note: Identification of endometrial is based on the characteristics of a rather thick round tissue that has tunica intima, tunica media, and tunica adventitia indicated by blue arrows in the image.

The spiral arterioles were identified by recognizing their shapes, i.e., round, thick, and having intima, media, and adventitia tissue. The number of endometrial arterioles was calculated manually in 10 visual fields with 200 times magnification, and the results were averaged.

One Way ANOVA test on the number of endometrial arterioles obtained $p$-value $0.001(<0.05)$ which showed significant differences in the number of endometrial arterioles in each group. Based on LSD test, the negative control group $\left(8,228 \pm 4.3074^{b}\right)$ was significantly different compared with the positive control group $\left(7.260 \pm 1.0065^{\mathrm{a}}\right)$. Thisshows a significant difference in the number of endometrial arterioles. In other words, exposure to lead acetate in female rats at a dose of $175 \mathrm{mg} / \mathrm{kg} / \mathrm{BW}$ can reduce the number of endometrial arterioles.

Table 2 also showed the results of the positive control group $\left(7.260 \pm 1.0065^{\mathrm{a}}\right)$ compared to the P3 group $\left(12.200 \pm 2.7359^{c}\right)$, indicating that there were significant differences in the mean number of arterioles. In other words, in the $\mathrm{P} 3$ group, chitosan $64 \mathrm{mg} / \mathrm{kg} / \mathrm{BW}$ was able to increase the number of arterioles in rats exposed to lead significantly.

Table. 2 One Way ANOVA Test Results on the Number of Arterioles between Groups

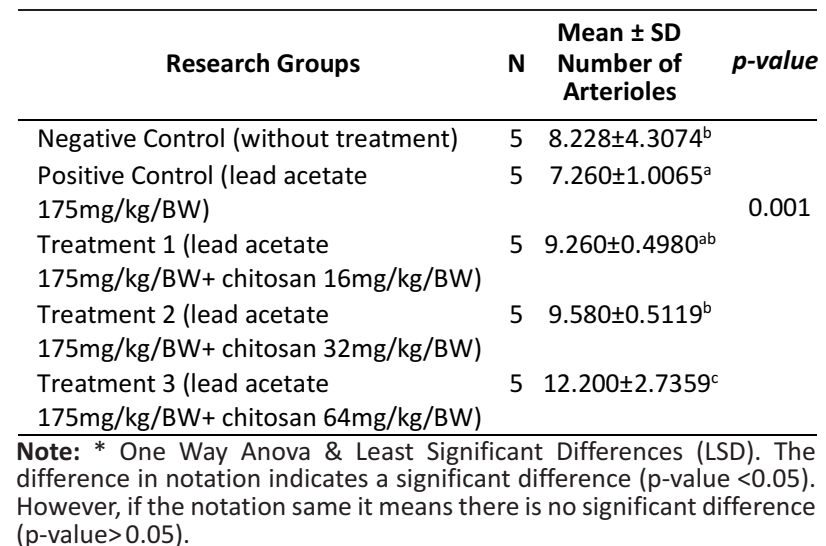

Therefore, it can be concludedthat lead exposure can increase the number of endometrial arterioles. At doses of $16 \mathrm{mg} / \mathrm{kg} / \mathrm{BW}$ and $32 \mathrm{mg} / \mathrm{kg} / \mathrm{BW}$, although there was an increase in the number of endometrial arterioles compared to lead-exposed rats, it was not able to significantly increase the diameter of antral follicles exposed to lead. The dose of chitosan $64 \mathrm{mg} / \mathrm{kg} / \mathrm{BW}$ was able to significantly increase the number of endometrial arterioles in rats exposed to lead.

Effect of Chitosan Administration for the Endometrial Thickness Induced by Lead

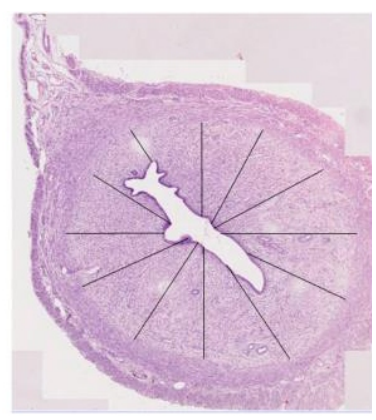

Figure 3. Microscopic measurement of endometrial thickness with $\mathbf{4 0 0}$ times magnification

Note: Identification of the measurement area boundary of endometrial thickness, from the epithelial lumen to the endometrial basal layer (shown by the black lines in the picture).

One Way ANOVA test on endometrial thickness obtained p-value $0.028(<0.05)$ which showed significant differences in the thickness of the endometrium of each group. In the LSD test, the negative control group (579.51 $\pm 105.63 \mathrm{~b})$ compared to the positive control group $(387.48 \pm 44.81 \mathrm{a})$ showed significant differences in endometrial thickness. In other words, exposure to lead acetate in female rats at a dose of $175 \mathrm{mg} / \mathrm{kg} / \mathrm{BW}$ was able to reduce endometrial thickness.

Table 3 also describes the results in the positive control group $\left(387.48 \pm 44.81^{\mathrm{a}}\right)$ compared to group $\mathrm{P} 1$ $\left(605.22 \pm 102.35^{b}\right)$, group P2 $\left(626.64 \pm 107.10^{b}\right)$, and group P3 $\left(616,26 \pm 193.59^{b}\right)$. The results showed that there were significant differences in the mean endometrial thickness in each group. P1, P2, and P3 groups were able to increase endometrial thickness in lead-exposed rats. However, P2 group significantly increased the endometrial thickness compared to group P1 and P3.

Table 3. One Way ANOVA test results endometrial thickness between groups

\begin{tabular}{|c|c|c|c|}
\hline Research Groups & $\mathbf{N}$ & $\begin{array}{c}\text { Mean } \pm \text { SD } \\
\text { Endometrial } \\
\text { Thickness }\end{array}$ & p-value \\
\hline Negative Control (without treatment) & 5 & $579.51 \pm 105.63^{b}$ & 0,028 \\
\hline $\begin{array}{l}\text { Positive Control (lead acetate } \\
175 \mathrm{mg} / \mathrm{kg} / \mathrm{BB} \text { ) }\end{array}$ & 5 & $387.48 \pm 44.81^{\mathrm{a}}$ & \\
\hline $\begin{array}{l}\text { Treatment } 1 \text { (lead acetate } \\
175 \mathrm{mg} / \mathrm{kg} / \mathrm{BB}+\text { chitosan } 16 \mathrm{mg} / \mathrm{Kg} / \mathrm{BB} \text { ) }\end{array}$ & 5 & $605.22 \pm 102.35^{b}$ & \\
\hline $\begin{array}{l}\text { Treatment } 2 \text { (lead acetate } \\
175 \mathrm{mg} / \mathrm{kg} / \mathrm{BB}+\text { chitosan } 32 \mathrm{mg} / \mathrm{Kg} / \mathrm{BB} \text { ) }\end{array}$ & 5 & $626.64 \pm 107.10^{b}$ & \\
\hline Treatment 3 (lead acetate & 5 & $616.26 \pm 193.59^{b}$ & \\
\hline
\end{tabular}

Note: * One Way Anova \& Least Significant Differences (LSD). The Note: $*$ One Way Anova \& Least Significant Differences (LSD). The
difference in notation indicates a significant difference ( $p$-value <0.05). difference in notation indicates a significant difference ( $p$-value $<0.05$ ).
However, if the notation same it means there is no significant difference ( $p$-value>0.05). 
Therefore, it can be concluded that lead exposure can reduce endometrial thickness. Administration of chitosan doses 16,32 , and $64 \mathrm{mg} / \mathrm{kg} / \mathrm{BW}$ can significantly increase endometrial thickness. However, the most effective dose of chitosan is a dose of $32 \mathrm{mg} / \mathrm{kg} / \mathrm{BW}$.

\section{DISCUSSION}

\section{Effect of Chitosan on Antral Follicles Exposed to Acetate Lead}

Lead acetate exposure in the female rat at a dose of $175 \mathrm{mg} / \mathrm{kg} / \mathrm{BW}$ can reduce the diameter of the antral follicle. The results of this study are in line with the research conducted by Ahmed et al., that the administration of lead doses of $30 \mathrm{mg} / \mathrm{kg}$ in experimental animals can increase follicular atresia, decrease the growth and maturity of follicles (25). According to the research of Dhir and Dhand, lead administration causes an increase in phosphoric acid in the ovary and shows the presence of phagocytosis (26). Lead that enters the bloodstream will flow into the soft tissue and can accumulate in the ovary. Ovaries have an important role in regulating the development, maturation, and ovulation of female gametes. Research shows that lead can cause direct damage to the ovary(11).

Infertility is associated with a decrease in the number and diameter of the antral follicle (27). The diameter of the antral follicle indicates that the antral follicle can receive a response from FSH and LH to develop so that it increases the number of granulosa cells to produce estradiol (28). The diameter of the follicle is used to increase follicular growth, oocyte growth, follicular fluid volume, and granulosa cell proliferation (12). The antral follicles grow because of FSH and LH stimulation. In the condition of lead toxicity, lead is able to pass through the BBB and affect to the role of $\mathrm{Ca}^{2+}$ as a second messenger, thereby disrupting cellular processes or cell function (10). This disruption regulate the work of the hypothalamus and the function of the pituitary gland, which results in disruption of sex hormone biosynthesis. Impaired biosynthetic stimulation causes FSH and LH decrease(11).

The decrease in $\mathrm{FSH}$ and $\mathrm{LH}$ (the protective toxicities of lead), will reduce the diameter of the antral follicle. Oxidative stress caused by lead exposure can distrub follicle growth by affecting the process of histological changes and cell components in the ovary, so that disrupting the growth of theca and granulosa cells (6). Lead exposure in female rats can reduce the diameter of the antral follicle. This is consistent with the research of Sharma et al., that lead exposed to female rats will affect the process of development and follicular growth(29).

The administration of chitosan in this study was able to increase the diameter of antral follicles of rats exposed to lead. This proves the administration of chitosan in leadexposed rat can inhibit the effects of lead toxicity by increasing the diameter of the antral follicle. Chitosan has antioxidant compounds that can reduce damage due to lead exposure (23). This is consistent with the study of Niu et al., which showed that people with foods given chitosan extract had lower MDA than the control group (30). Chitosan has an antioxidant mechanism through its ability to stabilize free radicals (scavenging) and bind metal ions (chelathing). Scavenging, because hydroxyl groups and amino groups in chitosan will donate electrons so that free radicals can be controlled and inhibit the oxidative chain (20). Chelathing, derived from an amino group which is a cation, will bind to heavy metals, especially lead (31).

Effect of Chitosan on the Number of Arterioles Exposed to Acetate Lead

Lead is a metal that is very toxic to both animals and humans, even in a low dose (11). Chronic lead exposure can disrupt the reproductive system, such as menstruation and ovulation inhibition, decrease follicle count, damage the endometrium, myometrium, and perimetrium (32). In the reproductive organs, lead toxicity can interfere the activity of the hypothalamus and the function of the pituitary gland which will result in a decrease in the biosynthesis of the hormones FSH and LH (6). Follicle Stimulating Hormone (FSH) and Luteinizing Hormone (LH) are important hormones synthesized by the pituitary gland, which are important in regulating the reproductive system. Research conducted by Dumitrescu et al., stated that lead could disrupt FSH function, increase LH levels significantly, and significantly reduce estradiol and progesterone levels (33). Non-optimal secretion of FSH and LH can cause impaired maturation and developmentof follicle, resulting in a decrease in the progesterone and estrogen hormones which play an important role in the menstrual cycle, endometrial proliferation, and myometrium. The estrogen and progesterone hormones have an important role in forming a new layer of blood vessels in the endometrium of each menstrual cycle. New blood vessel tissues are formed through angiogenesis and vascular remodeling from pre-existing vessels in the endometrial basal zone during each menstrual cycle (34) under the control of estrogen and progesterone (35). This process is an important factor in each menstrual cycle.

Apart from progesterone and estrogen, many factors play a role in angiogenesis, one of which is VEGF (Vascular Endothelial Growth Factor) (36). VEGF is a key compound of angiogenesis '(14). A decrease in VEGF can result in abnormal angiogenesis. Disrupted angiogenesis will disrupt blood vessel function such as abnormalities of bleeding during menstruation, amenorrhea, and failure of conception results.

The spiral arteriole is a uterine blood vessel that originates from the spiral arteries that supply $9 \mathrm{~mm}^{2}$ from the endometrial layer (15). Spiral arteriole maintains stable blood flow to the endometrial functionalist stratum (37). The spiral arteriole in the uterus plays an important role in the menstrual cycle and becomes the center of placental formation after embryo implantation.

Chitosan as an antioxidant agent has a hydroxyl group $(\mathrm{OH})$ and an amino group (Nh2), which is a key group to prevent the occurrence of free radicals (21). In the study of Vedy, proved that chitosan have capability for binding heavy metals to the kidneys induced by lead acetate with renal histopathological images of rats. There is a reduction in damaged cells after chitosan administration compared to positive controls. The administration of chitosan in this study was able to increase the number of arterioles of rats exposed to lead (38). This proves that the administration of chitosan in lead-exposed rats can inhibit the effects of lead by increasing the number of endometrial arterioles.

Effect of Chitosan on Endometrial Thickness Exposed to Acetate Lead 
Lead substitutes calcium (Ca2+) as a second messenger that binds to Calmodulin (CaM) so that protein kinase is inactive and cellular processes are impaired (2). This can disrupt the stimulation of hormone secretions caused by the damage on the hypothalamus and pituitary gland (6). Accumulation of exposure to lead acetate causes significant histological changes in the reproductive organs. This structural change is related to the level of exposure in the ovaries, uterus, and fallopian tubes. The reproductive organs experience edema and necrosis, denudation, and stages of abnormal follicle changes. The microscopic examination of the uterus and fallopian tube undergoes uterine gland necrosis at lead exposure of $0.150 \mathrm{mg} / \mathrm{L}^{-1}$. This changed indicates the occurrence of infertility in female rats (11). However, the administration of oral lead acetate solution was not proven to cause a decrease in the thickness of the endometrial layer due to the influence of an increase in free radicals (39). In uterus exposed to 100 and $300 p p m$ lead, cystic goblet cell degeneration and decay of the lining of endometrial epithelial cells occur. Degenerative and inflammatory changes in the uterus are in the form of a decrease in the height of columnar cells and areas of blood vessels, lymphatics, and connective tissue (40). The difference in changes in uterine histology in the treatment group depends on the dosage.

Besides that, lead acetate can cause lipid peroxidation and reduce SOD and GPx activity in rats' reproductive organs. Providing antioxidants can prevent oxidative stress conditions by increasing one of the antioxidant enzymes such as SOD (41). Chitosan is one of the antioxidant compounds which acts as an oxygen free radical scavenger

\section{REFERENCES}

1. Conant J and Fadem P. A Community Guide to Environmental Health. Berkeley, California; Hesperian; 2012: p. 368.

2. Flora SJS and Agrawal S. Chapter 31 - Arsenic, Cadmium, and Lead. In: Gupta RC (Ed). Reproductive and Developmental Toxicology 2nd edition. Canada: Elsevier; 2017: p. 537-566.

3. Nascimento CRB, Risso WE, and Martinez CBDR. Lead Accumulation and Metallothionein Content in Female Rats of Different Ages and Generations After Daily Intake of Pb-Contaminated Food. Environmental Toxicology and Pharmacology. 2016; 48: 272-277.

4. Gillis BS, Arbieva Z, and Gavin IM. Analysis of Lead Toxicity in Human Cells. BioMed Central Genomics. 2012; 13: 1-12.

5. Ayala A, Muñoz MF, and Argüelles S. Lipid Peroxidation: Production, Metabolism, and Signaling Mechanisms of Malondialdehyde and 4Hydroxy-2-Nonenal. Oxidative Medicine and Cellular Longevity. 2014; 2014: 1-31.

6. Flora SJS, Pachauri V, and Saxena G. Arsenic, Cadmium, and Lead. In: Gupta RC (Ed). Reproductive and Developmental Toxicology. Canada: Elsevier; 2011: p. 415-438.

7. Linardou $\mathrm{H}$, Kalogeras $\mathrm{KT}$, Kronenwett $\mathrm{R}$, et al. The Prognostic and Predictive Value of MRNA Expression which can inhibit the formation of free radicals, thus protecting the damage of testicular lead-induced rats (42). Chitosan acts as an ion exchanger and adsorbent to heavy metals including lead. An amino group is a cation capable of binding to lead heavy metals. The amino group as a chelating agent will bind lead heavy metal (31). If oxidative stress can be prevented, then the edema and necrosis of ovarian follicles and necrosis of the uterine gland will not occur. In this study, the endometrial cells observed were not necrosis and edema in the stroma which was described with no inter-cell spacing, no edema in the uterine gland, and no damage to epithelial cells. This results in an increase in endometrial thickness.

It can be concluded that the administration of chitosan has been proven to improve the condition of the reproductive system cells histologically, which effective dose at $32 \mathrm{mg} / \mathrm{KgBW}$. This is indicated by an increase in the diameter of the antral follicle, an increase in the number of endometrial arterioles, and an increase in the endometrial thickness of Wistar strain (Rattus norvegicus) rats exposed to sub-chronic lead acetate. In this study, chitosan administration can reduce oxidative stress caused by lead exposure.

\section{ACKNOWLEDGMENTS}

dr. Bambang Rahardjo Sp.O.G (K); dr. Hidayat Sujuti, Ph.D, SpM; Dr. Husnul Khatimah, S. Si, M. Kes; Dr.rer nat., Tri Yudani Mardining Raras, M.App.Sc; Prof.Dr.dr.Yuyun Yueniwati, M.Kes, Sp.RadK; Sri Austriani, S.KM; Didin Ari Sumanto, A.Mk.; Moch. Abuhari; Lasmijan SE. of Vascular Endothelial Growth Factor Family Members in Breast Cancer: A Study in Primary Tumors of High-Risk Early Breast Cancer Patients Participating in a Randomized Hellenic Cooperative Oncology Group Trial. Breast Cancer Research. 2012; 14(6): 1-16.

8. Sanders T, Liu Y, Buchner V, and Tchounwou PB. Neurotoxic Effects and Biomarkers of Lead Exposure: A Review. Reviews on Environmental Health. 2009; 24(1): 15-46.

9. Zorana KG, Alica $P$, and Jasna J. Influence of Abatement of Lead Exposure in Croatia on Blood Lead and ALAD Activity. Environmental Science and Pollution Research International. 2016; 23(1): 898907.

10. Carocci A, Catalano A, Lauria G, Sinicropi MS, and Genchi G. Lead Toxicity, Antioxidant Defense and Environment. Reviews of Environmental Contamination and Toxicology. 2016; 238: 45-47.

11. Dumitrescu E, Chiurciu V, Muselin F, Popescu R, Brezovan D, and CRISTINA RT. Effects of Long-Term Exposure of Female Rats to Low Levels of Lead: Ovary and Uterus Histological Architecture Changes. Turkish Journal of Biology. 2015; 39(2): 284-289.

12. Hsueh AJW, Kawamura K, Cheng Y, and Fauser BCJM. Intraovarian Control of Early Folliculogenesis. Endocrine Reviews. 2015; 36(1): 1-24.

13. Hamilton KJ, Hewitt SC, Arao Y, and Korach KS. Estrogen Hormone Biology. Current Topics in 
Developmental Biology. 2017; 125: 109-146.

14. Barrett KE, Barman SM, Boitano S, and Brooks HL. Ganong's Review of Medical Physiology. 24th edition. New York: Mc Graw HIII; 2012: p. 539-553.

15. Sadekova ON, Nikitina LA, Rashidov TN, et al. Luteal Phase Defect is Associated with Impaired VEGF MRNA Expression in the Secretory Phase Endometrium. Reproductive Biology. 2015; 15(1): 65-68.

16. Kanzaki H. Uterine Endometrial Function. New York: Springer; 2016: p. 1-155.

17. Mescher AL. Junqueira's Basic Histology: Text and Atlas. New York: McGraw-Hill Education; 2013.

18. Ivanovski M. The Role of Ultrasound in the Evaluation of Endometrial Receptivity Following Assisted Reproductive Treatments. (Online) 2012. https://www.intechopen.com/books/in-vitrofertilization-innovative-clinical-and-laboratoryaspects/the-role-of-ultrasound-in-the-evaluationof-endometrial-receptivity-following-assistedreproductive-.

19. Gupta P, Chandra S, Kaushik A, and Jain PK. Evaluation of Uterine Biophysical Profile and to Assess its Role in Predicting Conception among Unexplained Primary Infertility Patients. Indian Journal of Community Health. 2014; 26(4): 401-405.

20. Wang Z, Yan Y, Yu X, Li W, Li B, and Qin C. Protective Effects of Chitosan and Its Water-Soluble Derivatives Against Lead-Induced Oxidative Stress in Mice. International Journal of Biological Macromolecules. 2016; 83: 442-449.

21. Rajalakshmi A, Krithiga $\mathrm{N}$, and Jayachitra $\mathrm{A}$. Antioxidant Activity of the Chitosan Extracted from Shrimp Exoskeleton. Middle-East Journal of Scientific Research. 2013; 16(10): 1446-1451.

22. Mahdy Samar M, El-Kalyoubi MH, Khalaf MM, and Abd El-Razik MM. Physicochemical, Functional, Antioxidant and Antibacterial Properties of Chitosan Extracted from Shrimp Wastes by Microwave Technique. Annals of Agricultural Sciences. 2013; 58(1): 33-41.

23. Ngo DH and Kim SK. Antioxidant Effects of Chitin, Chitosan, and Their Derivatives. Advances in Food and Nutrition Research. 2014; 73: 15-31.

24. Sari Al, Destriani SN, Soeharto S, and Raharjo B. Aktivitas Antioksidan Kitosan pada Ovarium Tikus Betina yang Terpapar Timbal ( Pb ) Asetat. 2018; 4(2): 80-86. JUDUL JURNAL??

25. Ahmed YF, Eldebaky H, Mahmoud KGM, and Nawito M. Effects of Lead Exposure on DNA Damage and Apoptosis in Reproductive and Vital Organs in Female Rabbits. Global Veterinaria. 2012; 9(4): 401-408.

26. Dhir $\mathrm{V}$ and Dhand P. Toxicological Approach in Chronic Exposure to Lead on Reproductive Functions in Female Rats (Rattus Norvegicus). Toxicology International. 2010; 17(1): 1-7.

27. Silva-Santos KC, Marinho LSR, Santos GMG, et al. Ovarian Follicle Reserve: Emerging Concepts and Applications. Animal Reproduction. 2013; 10(3): 180-186.
28. Sánchez F and Smitz J. Molecular Control of Oogenesis. Biochimica et Biophysica Acta. 2012; 1822(12): 1896-1912.

29. Sharma R, Qureshi N, Mogra S, and Panwar K. Lead Induced Infertility in Swiss Mice and Role of Antioxidants. Universal Journal of Environmental Research and Technology. 2012; 2(2): 72-82.

30. Niu J, Lin HZ, Jiang SG, et al. Comparison of Effect of Chitin, Chitosan, Chitosan Oligosaccharide and NAcetyl-D-Glucosamine on Growth Performance, Antioxidant Defenses and Oxidative Stress Status of Penaeus Monodon. Aquaculture. 2013; 372-375: 1-8.

31. Riswanda T. Pemanfaatan Kitosan Udang Putih (Lithopannaeus Vannamei) sebagai Bioabsorben Logam Berat Timbal (Pb) pada Daging Kerang Tahu di Muara Sungai Gunung Anyar. LenteraBio: Berkala Ilmiah Biologi. 2014; 3(3): 266-271.

32. Nakade UP, Garg SK, Sharma A, et al. Lead-Induced Adverse Effects on the Reproductive System of Rats with Particular Reference to Histopathological Changes in Uterus. Indian Journal of Pharmacology. 2015; 47(1): 22-26.

33. Dumitrescu E, Cristina RT, and Muselin F. Turkish Journal of Biology Reproductive Biology Study of Dynamics of Female Sexual Hormones: A 12-Month Exposure to Lead Acetate Rat Model. Turkish Journal of Biology. 2014; 38: 581-585.

34. Chianeh YR and Rao P. Molecular and Hormonal Regulation of Angiogenesis in Proliferative Endometrium. International Journal of Research in Medical Science. 2014; 2(1): 1-9.

35. Girling JE and Rogers PAW. Regulation of Endometrial Vascular Remodelling: Role of the Vascular Endothelial Growth Factor Family and the Angiopoietin-TIE Signalling System. Reproduction. 2009; 138(6): 883-893.

36. Keman K. Patomekanisme Preeklampsia Terkini: Mengungkapkan Teori-Teori Terbaru tentang Patomekanisme Preeklampsia Dilengkapi dengan Deskripsi Biomokuler. Malang: Universitas Brawijaya Press; 2014.

37. Lee SR, Lim YM, Jeong KA, and Chung H. Office Hysteroscopic Findings of Congested Endometrial Spiral Arterioles as Numerous Tiny Black Turtuous Lesions. The Journal of Minimally Invasive Gynecology. 2017; 24(2): 191-192.

38. Vedy HI. Efektifitas Kitosan Sebagai Absorben Logam Berat pada Gambaran Anatomi Ginjal Mencit (Mus Musculus L) yang Dinduksi Plumbum Asetat. Medical Journal of Lampung University. 2015; 4(7): 77-80.

39. Diantini NSE. Pengaruh Paparan Timbal Asetate Peroral Terhadap Peningkatan Kadar Malondialdehyde (Mda) Uterus Dan Penurunan Tebal Endometrium Tikus Putih (Rattus Norvegicus) Galur Wistar. [Tesis]. Universitas Brawijaya, Malang. 2016.

40. Qureshi N and Sharma R. Lead Toxicity and Infertility in Female Swiss Mice: A Review. Journal of Chemical, Biological and Physical Sciences. 2012; 2(4): 18491861.

41. Maulana HI, Ulilalbab A, Priyanto AD, dan Estiasih T. 
Effervescent Rosela Ungu Mencegah Penurunan Nilai SOD dan Mencegah Nekrosis Hepar Tikus Wistar yang Diberi Minyak Jelantah. Jurnal Kedokteran Brawijaya. 2014; 28(2): 85-90.
42. Wardani G and Sudjarwo SA. In Vitro Antibacterial Activity of Chitosan Nanoparticles Against Mycobacterium Tuberculosis. Pharmacognosy Journal. 2018; 10(1): 162-166 